\title{
Twenty-five years later
}

\author{
Massimo Cuzzolaro ${ }^{1}$
}

Received: 10 June 2020 / Accepted: 10 June 2020 / Published online: 17 June 2020

(c) Springer Nature Switzerland AG 2020

I left the editor-in-chief position of Eating and Weight Disorders (EaWD) in June 2020. The journal is now directed by two colleagues to whom I am bound by great esteem and sincere friendship: Lorenzo M. Donini (Editor-in-Chief) and Giovanni Abbate Daga (Co-Editor).

I founded EaWD in 1996, with the help of Ottavio Bosello, Paul Garfinkel, Nazario Melchionda, and Canzio Fusé, a brave Italian publisher. I directed the journal for 25 years. Over time, EaWD has moved from paper to electronic format, has become an official organ of SISDCA (Italian society for the study of eating disorders) and SIO (Italian society of obesity), and has acquired growing international credit. Since 2013 EaWD is published by Springer Nature, leading international publisher of scientific journals and books in the world. The first quarterly publication has become bi-monthly since 2018 .

Founding and leading a scientific journal has been a challenging and fascinating adventure, an opportunity for contact with researchers and clinicians from all over the world, a lifelong learning experience, where you learn by teaching.

Time has come for me to pass the baton into the skillful hands of Lorenzo and Giovanni and the excellent team that has been created over time. I want to thank all the co-editors, the reviewers, Patrizia Bianchi, Sara Ho, the editorial staff, and the proofreaders. They have contributed substantially to the remarkable growth of the journal.
I trust that the work will continue along the lines that have inspired the birth and life of EaWD so far:

- To pay attention to the deep intersections between the fields of feeding and eating disorders and obesity throughout the life cycle and gender differences.

- To develop and critically analyze the multidimensional, bio-psycho-social approach to these phenomena. An older, more enigmatic, and evocative expression would probably have defined this perspective with the word 'psychosomatic'. In 1818, Johann Christian August Heinroth coined a German compound adjective, Psychisch// somatisch, ${ }^{1}$ which, in the Gothic spelling of the time, through the double bar of separation, expressed both a distance and a mysterious nexus (Fig. 1).

- Finally, to use the evaluation of the submitted manuscripts as an educational opportunity. This attitude is especially useful for young researchers. The multifaceted procedure of reviewing articles should always keep scientific and ethical rigour, support, and kindness together.

I wish all the best to Lorenzo, Giovanni, and all friends of EaWD.

Massimo Cuzzolaro
Massimo Cuzzolaro

massimo.cuzzolaro@gmail.com

1 Formerly Sapienza University of Rome, Rome, Italy

\footnotetext{
${ }^{1}$ Heinroth JCA. Lehrbuch der Störungen des Seelenlebens oder der Seelenstörungen und ihrer Behandlung. Vom rationalen Standpunkt aus entworfen. Leipzig: Vogel; 1818.
} 
Fig. 1 Psychisch//somatisch (Heinroth, JCA, 1818, vol. II, p. $49, \S 313)$
Funding This work was not funded.

\section{Compliance with ethical standards}

Conflict of interest The author declares that he has no conflict of interest.

Ethical approval The article is an Editorial and did not need ethical approval.
Derfabren ju beftimmen. Bewóbnlid find oie Quellen

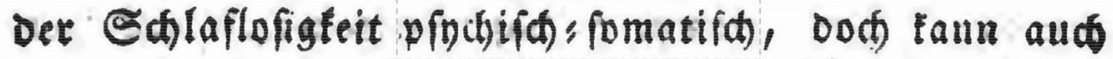

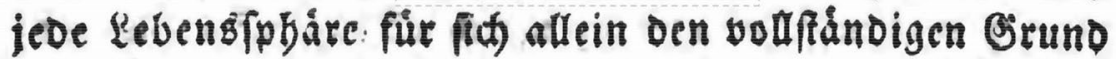
Derfelben entbalten. Mir (a)lafen fdon in gefunden. Sagen nid)t, wenn din (Begenftano unier Intereffe leb: baft bejoảftigt; eben. fo fliebt:uns ber Salef, wenn. Lebrb. D. Esclcu= etor. II.
Informed consent Informed consent is not required for this Editorial.

Publisher's Note Springer Nature remains neutral with regard to jurisdictional claims in published maps and institutional affiliations. 